\begin{tabular}{|l|l|l|}
\hline \multicolumn{2}{|c|}{ PublisherInfo } \\
\hline \hline PublisherName & $:$ & BioMed Central \\
\hline \hline PublisherLocation & $:$ & London \\
\hline \hline PublisherImprintName & $:$ & BioMed Central \\
\hline \hline
\end{tabular}

\title{
Evidence for increased risk of venous thrombosis during air travel
}

\begin{tabular}{|c|c|c|}
\hline \multicolumn{3}{|c|}{ ArticleInfo } \\
\hline ArticleID & : & 37 \\
\hline ArticleDOI & : & 10.1186/cvm-2001-72061 \\
\hline ArticleCitationID & : : & 72061 \\
\hline ArticleSequenceNumber & : : & 16 \\
\hline ArticleCategory & : : & Paper Report \\
\hline ArticleFirstPage & : : & 1 \\
\hline ArticleLastPage & : : & 3 \\
\hline ArticleHistory & : : & $\begin{array}{ll}\text { RegistrationDate } & : 2001-10-18 \\
\text { Received } & : 2000-11-28 \\
\text { OnlineDate } & : 2001-10-18\end{array}$ \\
\hline ArticleCopyright & : & Biomed Central Ltd2001 \\
\hline
\end{tabular}




\begin{tabular}{|l|l|l||}
\hline ArticleGrants & $:$ & \\
\hline \hline ArticleContext & $:$ & 1306322 \\
\hline
\end{tabular}

Joanna Lyford, ${ }^{\text {Affl }}$

Corresponding Affiliation: Aff1

Aff1 Medwire 28-11-00, UK

\section{Keywords}

Acute hypobaric hypoxia, air travel, venous thrombosis

\section{Context}

Healthy volunteers show increased activity of blood coagulation factors after spending just $2 \mathrm{~h}$ in a hypobaric chamber that simulates an aeroplane cabin at cruising altitude. According to a letter published in the Lancet which outlines a Norwegian study, the recent disputed reports of a link between venous thrombosis and air travel are 'probably clinically relevant' and deserve further investigation.

\section{Significant findings}

All participants had normal hemostasis before entering the chamber; however, after just two hours, concentrations of prothrombin fragments 1 and 2 and thrombin-antithrombin complex and activity of factor VIIa had increased significantly $(\mathrm{P}=0.008, \mathrm{P}=0.04$, and $\mathrm{P}=0.008$, respectively), whereas concentrations of factor VII antigen $(\mathrm{P}=0.003)$, activity of tissue-factor-pathway inhibitor $(\mathrm{P}=0.001)$ and concentrations of free antigen $(\mathrm{P}=0.02)$ decreased. Concentrations of prothrombin fragments 1 and 2 increased to a maximum of 2.5 -fold at $2 \mathrm{~h}$, whereas concentrations of thrombin-antithrombin complex increased 8.2-fold. This increase was associated with an increase of up to $17 \%$ in factor VIIa activity, a $4.9 \%$ decrease in factor VII antigen concentrations, a $10 \%$ decrease in the activity of tissue-factorpathway inhibitor and a 17\% (14-21\%) decrease in free antigen concentrations. Concentrations of Ddimer - a marker of continuing fibrinolysis - remained unchanged throughout the experiment.

\section{Comments}


'Despite the lack of an adequate control group at normal atmospheric pressure, our study suggests that rapid exposure to an air pressure encountered in aeroplane cabins activates coagulation', the authors write. 'This activation is probably clinically relevant and may contribute to the increased risk of venous thrombosis.' The team suggest that airlines take measures to reduce this risk, including advice to customers on how to use a muscle-vein pump to prevent stasis and regular provision of non-alcoholic drinks to prevent dehydration. High-risk individuals should consider medical thromboprophylaxis, such as low-molecular-weight heparin.

\section{Methods}

Bendz and colleagues from Ulleval University Hospital, Norway, exposed 20 healthy volunteers to hypobaric pressure $(76 \mathrm{kPa})$ for at least eight hours; this air pressure corresponds to the atmospheric pressure at $2400 \mathrm{~m}$ and is similar to the pressure in aeroplane cabins.

\section{Additional information}

\section{References}

1. Bendz B, Rostrup M, Sevre K, Andersen TO, Sandset PM: Association between acute hypobaric hypoxia and activation of coagulation in human beings. Lancet. 2000, 356: 1657-1658. 